\title{
Model Loyalitas Pelanggan Klinik Kecantikan
}

\author{
Kamiluddin \\ Magister Manajemen, Manajemen Pemasaran, Fak. Ekonomi, Universitas Sriwijaya \\ Jalan Bukit Lama, Kec. Ilir Bar. I, Kota Palembang, Sumatera Selatan 30128, Indonesia
}

*Koresponden : kamil.coetein@gmail.com

\section{Artikel Info \\ Received: \\ 14 September 2020 \\ Revised: \\ 20 September 2020 \\ Accepted: \\ 30 Oktober 2020}

Published by Jurnal Ilmiah Manajemen dan Bisnis, Indonesia | Copyright (C) 2020 by the Author(s) | This is an open access article distributed under the Creative Commons Attribution License

http://creativecommons.org/licenses by/4.0), which permitsunrestricted use distribution, and reproduction in any medium, provided the original work is properly cited.

\begin{abstract}
ABSTRAK
Penelitian ini bertujuan untuk menganalisa faktor-faktor yang mempengaruhi loyalitas pelanggan di kota palembang. Sampel yang akan digunakan dalam penelitian ini adalah pelanggan yang rutin mengunjungi klinik kecantikan di kota palembang yang terdiri dari pria dan wanita dari dua klinik kecantikan dengan usia antara 15 tahun sampai 65 tahun dan sudah menjadi pelanggan sejak lama. Sampel dari responden terdiri dari 101 orang menggunakan pertanyaan kuesioner skala likert dan di analisa menggunakan Structural Equation Modeling (SEM) program SPSS Amos 24. Hasil penelitian menunjukkan bahwa adanya mediasi (intervening) dari variabel kepuasan yang menyebabkan pengaruh tidak langsung antara profesional ahli medis dan kualitas pelayanan terhadap loyalitas pelanggan mempunyai nilai lebih besar daripada pengaruh langsung. Kualitas pelayanan berpengaruh positif dan signifikan terhadap kepuasan pelanggan. Pengaruh Positif tersebut adalah signifikan, Sehingga dapat disimpulkan bawah kepuasan pelanggan berpengaruh positif dan signifikan terhadap loyalitas pelanggan di klinik kecantikan kota Palembang.
\end{abstract}

KATA KUNCI: Kualitas produk; kualitas pelayan; Legalitas produk; Kenyamanan klinik; Profesionalisme ahli medis; Kepuasan pelanggan terhadap loyalitas.

\section{Beauty Clinic Customer Loyalty Model}

\begin{abstract}
This study aims to analyze the factors that affect customer loyalty in the city of Palembang. The sample that will be used in this study are customers who regularly visit beauty clinics in Palembang, consisting of men and women from two beauty clinics aged between 15 and 65 years and have been customers for a long time. The sample of respondents consisted of 101 people using a Likert scale questionnaire and analyzed using the SPSS Amos 24 program's Structural Equation Modeling (SEM). The results showed that there was a mediation (intervening) of the satisfaction variable which caused an indirect influence between professional medical professionals and quality. service to customer loyalty has a greater value than direct influence. Service quality has a positive and significant effect on customer satisfaction. This positive influence is significant, so it can be concluded that customer satisfaction has a positive and significant effect on customer loyalty in the Palembang city beauty clinic.
\end{abstract}

Keywords: Product quality; service quality; product legality;clinical comfort; professional medical professionalism; customer satisfaction with loyalty.

DOI: $h$ htps://doi.org/10.30596/jimb.v21i2.5060

JEL CLASSIFICATION: M, M3, M31

Cara Sitasi :

Kamiluddin. (2020). Model Loyalitas Pelanggan Klinik Kecantikan. Jurnal Ilmiah Manajemen dan Bisnis, 21(2), 174-190. https://doi.org/10.30596/jimb.v21i2.5060. 


\section{PENDAHULUAN}

Perawatan kecantikan telah menjadi kebutuhan yang dianggap penting bagi sebagian masyarakat khususnya bagi kaum wanita. Fenomena tersebut mendukung munculnya banyak klinik perawatan kecantikan kulit wajah yang menawarkan produk dan jasanya untuk memenuhi kebutuhan kecantikan dan perawatan kulit wajah. Hal ini berkaitan erat dengan strategi pemasaran yaitu Segmenting, Targeting, Positioning.

Para wanita rela mengeluarkan biaya besar untuk melakukan perawatan kecantikan. Kaum pria juga pada saat ini sudah banyak yang memperhatikan kesehatan kulit wajah dengan cara merawat kulit wajah dan mendatangi klinik kecantikan perawatan kulit wajah. Perilaku konsumen tersebut menyebabkan kebutuhan akan kecantikan kulit wajah semakin meluas pada kelompok masyarakat khususnya mereka yang memperhatikan penampilan serta kecantikan kulit wajah. Melihat kenyataan tersebut, maka banyak bermunculan jasa klinik kecantikan perawatan kulit wajah yang menawarkan berbagai macam perawatan wajah, rambut dan body. Fenomena ini bagi praktisi pemasaran adalah peluang untuk menentukan strategi pemasaran. Dari data Dinas Kesehatan Kota Palembang, Dinas Penanaman Modal dan Perijinan Kota Palembang pada tahun 2013 jumlah klinik kecantikan di Palembang yang sudah mempunyai ijin operasional sebanyak 13 klinik kecantikan, kemudian pada tahun 2016 berkembang menjadi 24 klinik kecantikandan, dan pada awal tahun 2020 jumlah klinik kecantikan di Palembang yang sudah mempunyai ijin operasional menjadi 58 klinik kecantikan.

Jumlah klinik kecantikan yang bertambah juga menjadikan konsumen memiliki lebih banyak pilihan. Selain itu pelanggan juga semakin cerdas, sadar harga, sadar legalitas dan keamanan produk, banyak menuntut, sehingga menyebabkan pelanggan tidak mudah terpuaskan. Beberapa klinik kecantikan yang peniliti amati, terjadinya penurunan jumlah pelanggan karena pelanggan berpindah ke klinik kecantikan lainnya. Fenomena ini sering disebut perpindahan merk (Brand Swiching). Andrie Kurniawan (2016), perilaku perpindahan merek merupakan fenomena yang kompleks, yang dapat terjadi karena adanya perilaku mencari keberagaman (variety seeking), terdapatnya penawaran produk lain atau dapat juga terjadi karena adanya masalah yang ditemukan atas produk yang sudah di konsumsi. Dengan kata lain fenomena yang terjadi menunjukkan suatu kecenderungan adanya ketidak puasan dari pelanggan.

Menurut Yulia (2014), kebutuhan dan selera konsumenpun terus bergeser dari waktu ke waktu. Penelitian Yulia pada pelanggan provider IM3 ini juga menyimpulkan bahwa kepuasan konsumen yang rendah akan membuat konsumen memiliki minat perpindahan merek. Donni (2017:196), menciptakan kepuasan konsumen merupakan salah satu inti dari pencapaian profitabilitas jangka panjang bagi perusahaan. Dari uraian tersebut kepuasan pelanggan adalah merupakan gambaran perbedaan antara harapan dan kinerja nyata yang diterima pelanggan Apabila harapan tinggi, sementara kinerjanya biasa-biasa saja maka kepuasan tidak akan tercapai atau bahkan menimbulkan kekecewaan bagi konsumen. Sebaliknya apabila kinerja melebihi dari yang diharapkan maka kepuasan akan meningkat. Oliver (1997:10) satisfaction can be likened to an individual pursuit, a goal to be attained from the consumption of products and the patronization of services.

Kepuasan pelanggan (satisfaction) merupakan fungsi kinerja yang dipersepsikan terhadap jasa yang ditawarkan dan ekspektasi pelanggan, dengan mengenali bahwa kepuasan yang tinggi menimbulkan loyalitas pelanggan yang tinggi. Loyalitas pelanggan yang tinggi sangat mempengaruhi laba perusahaan. Biaya untuk mendapatkan pelanggan baru diperkirakan lima kali lipat biaya mempertahankan pelanggan lama. Pelanggan loyal akan selalu membela institusi bahkan berusaha pula untuk mengajak ikut serta dan memberi saran kepada orang lain untuk menjadi pelanggan. Perilaku pelanggan yang diharapkan tetap terus berlaku bagi perusahaan adalah loyalitas (Loyality). Menurut Donni (2017:211) Terciptanya kepuasan di hati konsumen sangat bermanfaat untuk menumbuhkan loyalitas pelanggan terhadap perusahaan. 
Loverlock and Wright (2005:133) menyatakan bahwa loyalitas adalah keputusan konsumen untuk secara sukarela terus berlangganan dengan perusahaan tertentu dalam jangka waktu yang lama. Blackwell et.al (2012:53) customer loss can be disastrous because there are fewer new consumers to replace those who leave. Therefore, customer loyalty based on genuine and ongoing satisfaction is one of the greatest assets a firm can develop. Dijelaskan oleh Margarita (2016) bahwa menciptakan loyalitas pelanggan merupakan salah satu strategi kontemporer yang paling signifikan, tidak hanya kesuksesan bisnis perusahaan tetapi juga terciptanya pelanggan setia jangka panjang.

Menurut Margarita (2016) sebuah perusahaan perlu memiliki pelanggan tetap dan loyal yang membeli barang berulang kali, memberikan informasi positif, dan tidak akan membeli barang alternatif dari pesaing. Produk berkualitas mempunyai peranan penting untuk membentuk kepuasan pelanggan (Eugina dan Suryono, 2016). Produk berkualitas juga memenuhi persyaratan legalitas yang sudah ditentukan Pemerintah (Badan Pengawas Obat Dan Makanan).

Disamping penyediaan produk yang memenuhi ketentuan kualitas dan legalitas, faktor penting lainnya yang mempengaruhi loyalitas pelanggan adalah faktor pelayanan. Apabila pelanggan merasa puas dengan pelayan yang diberikan oleh klinik kecantikan perawatan kulit wajah maka pelanggan akan kembali mengunjungi klinik tersebut sehingga terbentuklah pelanggan yang loyal. Pelanggan adalah pemaksimal nilai, mereka membentuk ekspektasi nilai dan bertindak berdasarkan nilai tersebut. Pelanggan akan membeli dari perusahaan yang mereka anggap menawarkan nilai tertinggi yang akan mereka terima. Penelitian Jackson R.S.Weenas (2013) menyebutkan kualitas pelayanan menjadi factor yang penting dalam menarik minat beli dan daya beli konsumen.

Kotler dan Keller (2009) kepuasan (satisfaction) adalah perasaan senang atau kecewa seseorang yang timbul karena membandingkan kinerja yang dipersepsikan produk (atau hasil) terhadap ekspekasi mereka. Jika kinerja gagal memenuhi ekspektasi, pelanggan akan tidak puas. Jika kinerja sesuai dengan ekspektasi maka pelanggan akan puas. Jika kinerja melebihi ekspektasi pelanggan, pelanggan akan sangat puas atau senang. Donni (2016), terciptanya kepuasan di hati konsumen sangat bermanfaat bagi tumbuhnya loyalitas/kesetiaan merk. Basu (1999) konsumen yang memperoleh kepuasan atas produk yang dibelinya cenderung melakukan pembelian ulang produk yang sama. Fandy dan Chandra (2015:201) manfaat spesifik dari kepuasan pelanggan meliputi keterkaitan positif dengan loyalitas pelanggan yang berpotensi menjadi sumber pendapatan perusahaan dimasa akan datang. Gissela dan Anik (2017), kepuasan pelanggan adalah salah satu tujuan perusahaan agar dapat memenuhi kebutuhan, keinginan dan ekspektasi pelanggan pada suatu produk/jasa sehingga pelanggan menjadi loyal.

Jill Griffin (2002) mengungkapkan apabila kepuasaan pelanggan tidak dapat diandalkan, pengukuran yang terkait dengan pembelian ulang adalah loyalitas pelanggan (customer loyalty).

Rabeca and Adrian (2017) customer satisfaction is an assessment of how well a company's products or services meet customer expectations. Engel et. al menyatakan pengetahuan produk merupakan kumpulan berbagai macam informasi mengenai produk ( Donni, 2016). Pengetahuan ini meliputi kategori produk, merek, terminologi produk, atribut atau fitur produk, harga produk, dan kepercayaan mengenai produk. Eugenia dan Suryono (2016) perhatian utama perusahaan agar dapat memenangkan persaingan adalah memberikan nilai dan kepuasan kepada konsumen melalui penyampaian produk dan jasa yang berkualitas dengan harga bersaing. Florensia et.al (2014) kualitas dan kepuasan pelanggan berkaitan erat dengan pangsa pasar dan retensi pelanggan. Salah satu faktor penting yang dapat membuat konsumen puas adalah kualitas.

Kualitas pelayanan menjadi salah satu ukuran atas keberhasilan dalam memberikan jaminan atas kepuasan bagi konsumen, melalui kualitas pelayanan seorang konsumen dapat memberikan penilaian secara obyektif dalam usaha menciptakan kepuasan konsumen. Menurut Griffin (2005) seorang pelanggan yang loyal memiliki prasangka spesifik mengenai apa yang 
akan di beli dan dari siapa dia membeli. Wu and Ai mengungkapkan having loyal customers is a required option for various companies based on its important role in creating sustainable competitive advantages ( Saifalddin et.al , 2018).

Berbagai produk kosmetik yang ada di pasar pada saat ini baik pemasaran di super market, mall, pemasaran di media soial, media elektronik, di klinik kecantikan seharusnya mempunyai legalitas yang ditentukan dan kemanfaatan serta tingkat keamanan dalam pemakaiannya. Produk tersebut mempunyai legalitas yang sudah teregistrasi di Balai Pengawas Obat Dan Makanan (BPOM), tidak membahayakan kulit saat pemakaiannya. Penny (2016) perlindungan konsumen terhadap keamanan dan kemanfaatan produk merupakan isu yang cukup penting, karena kosmetika sudah merupakan produk kebutuhan sehari-hari. Fatma Riska et.al (2019) legalitas produk kosmetika yang sudah mempunyai ijin edar dari BPOM RI merupakan perlindungan dan keamanan bagi konsumen. Ratnawulan et.al (2017), pilihlah kosmetika yang telah memiliki izin edar berupa notifikasi dari Badan POM.

Penataan ruangan pada klinik kecantikan diciptakan supaya pelanggan merasakan kenyamanan dan pelanggan mempunyai persepsi akan nilai serta keyakinan mereka pada klinik kecantikan yang di kunjungi. Menurut Nofiawaty dan Yuliandi (2014) store atmosphere tidak hanya dapat memberikan suasana lingkungan pembelian yang menyenangkan saja, tetapi juga dapat memberikan nilai tambah terhadap produk yang dijual. Mete and senem (2014), Suasana toko dapat digambarkan sebagai suasana umum di mana semua jenis stimulan terlibat. Suasana toko dapat mempengaruhi minat dan persepsi pelanggan. Penataan yang perlu seperti dekorasi toko, bentuk produk, paket perawatan, penyajian produk di dalam toko, warna, pencahayaan, ventilasi, aroma, musik, penampilan perwakilan penjualan dan sikap mereka terhadap pelanggan yang mengunjungi klinik kecantikan.

Berdasarkan hasil penelitian Faisal Marzuki (2018) terdapat pengaruh positif anatara profesionalisme terhadap loyalitas. Profesionalisme yang diharapkan adalah memiliki keahlian, tanggung jawab sosial dan mampu bekerjasama. Yusfi (2010) mengemukakan, dokter umum/ dokter spesialis yang memberi pelayanan di klinik kecantikan harus mengacu kepada peraturan/pedoman penyelenggaraan klinik kecantikan sehingga tidak menimbulkan sengketa. Purnamasari et al (2015) profesionalisme menjadi kompetensi utama yang wajib dikuasai oleh seorang dokter. Dokter estetika yang melayani pasien pada klinik kecantikan sudah mengikuti pelatihan, seminar estetika. Beberapa dokter sudah ada yang meneruskan pendidikan estetika atau anti aging pada perguruan tinggi tertentu sehingga keahlian yang didapatkan menambah tingkat kepercayaan terhadap pelayanan dan tindakan medis terhadap pelanggan klinik estetika. Perawatan di klinik kecantikan kulit wajah untuk tindakan medis dilakukan oleh ahli medis (dokter). Untuk kasus yang lebih ringan seperti facial wajah dan memberikan obat anti acne atau obat pencerah kulit dilakukan oleh ahli kecantikan (beautician) dengan pengawasan dokter. Menurut Yusfi Risna (2010), berbagai masalah sering terjadi dalam pelayanan klinik kecantikan mulai dari keluhan ringan seperti tidak mendapatkan hasil sesuai dengan yang dijanjikan sampai dengan terjadinya kematian. Disebutkan salah satu masalah yang paling krusial dibidang kedokteran estetika adalah masalah kompetensi, karena kedokteran estetika ini melibatkan berbagai disiplin ilmu dari beberapa bidang spesialisasi kedokteran. Keinginan pasien untuk tampil lebih cantik, selalu awet muda menjadi penting bagi dokter estetika untuk memberikan pelayanan maksimal sesuai kompetensi yang dimiliki.

Menurut Ferdinand (2014), model atau sering disebut kerangka pemikiran teoritis adalah penyederhanaan dari fenomena dunia nyata yang membentuk satu pemahaman pengertian yang utuh mengenai bagaimana sebuah masalah dipecahkan. Nurlina at.al (2017), apabila suatu konsep memiliki lebih dari satu keadaan, nilai atau kondisi, konsep tersebut merupakan variabel. Variabel juga merupakan proksi atau representasi dari konstruk yang dapat diukur dengan berbagai macam nilai (penilaian). Variabel menjadi mediator konstruk yang bersifat abstrak dan 
fenomena yang bersifat nyata. Variabel Independen dalam penelitian ini adalah Produk (Product), Pelayanan (Service), Legalitas (Legality), Kenyamanan klinik (Store Atmosphere), Profesi (Profession). Sedangkan Kepuasan pelanggan (Customer Satisfaction) merupakan variabel Intervening.

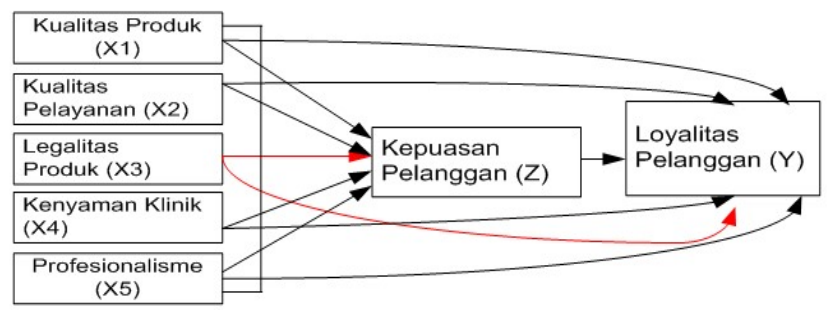

Gambar 1: Kerangka konseputal

Hipotesis pada penelitian ini adalah untuk menguji pengaruh sebab-akibat (kausalitas) antara variabel-variabel Independen dan variabel Dependen atau pengaruh antara variabel Eksogen dan variabel Endogen. Menurut Eugenia dan Suryono (2016) pengujian hipotesis dalam penelitian dapat dinyatakan pada nilai Critical Ratio (CR) dari suatu hubungan kausalitas.

H1. Kualitas Produk berpengaruh positif dan signifikan terhadap kepuasan pelanggan. H2. Kualitas pelayanan berpengaruh positif dan signifikan terhadap kepuasan pelanggan. H3. Legalitas Produk berpengaruh positif dan signifikan terhadap kepuasan pelanggan. H4. Kenyamanan klinik berpengaruh positif dan signifikan terhadap kepuasan pelanggan. H5. Profesionalisme ahli medis berpengaruh positif dan signifikan terhadap kepuasan pelanggan H6. Kepuasan Pelanggan berpengaruh positif dan signifikan terhadap loyalitas pelanggan

\section{METODE}

Penelitian ini menggunakan metode kuantitatif, menganalisa faktor-faktor yang mempengaruhi loyalitas pelanggan klinik kecantikan di Palembang. Ruang lingkup penelitian adalah kepuasan dan loyalitas pelanggan klinik kecantikan, merupakan perilaku sosial kelompok masyarakat tertentu di kota Palembang. Burhan Bungin (2011) perilaku sosial yang memiliki gejala yang tampak, dapat diamati, ditentukan dalam konsep, dan dapat diukur sebagai variabelvariabel yang muncul di masyarakat. Nurlina (2017) suatu konsep yang memiliki lebih dari suatu keadaan, nilai, atau kondisi maka konsep tersebut adalah variabel. Variabel Independen dalam penelitian ini adalah Kualitas Produk (X1), Kualitas Pelayanan (X2), Legalitas Produk (X3), Kenyamanan klinik (X4), Profesionalisme (X5), Variabel Dependen adalah Loyaltas Pelanggan (Y). Sedangkan Kepuasan pelanggan (Z) merupakan variabel Intervening. Sumber data dari penelitian ini adalah data primer dan data sekunder. Data sekunder merupakan data untuk melengkapi data primer. Data primer yaitu pelanggan klinik kecantikan di kota Palembang yang yang telah ditentukan sebelumnya. Data sekunder merupakan data untuk melengkapi dan mendukung penelitian ini yaitu dari klinik kecantikan yang dikunjungi oleh pelanggan, data Dinkes, DPMP, BPS, BPOM kota Palembang, literatur perpustakaan, jurnal, artikel, dan data terkait lainnya. Kreteria Responden terdiri dari wanita dan pria, sudah menjadi pelanggan di atas 2 tahun, usia antara 15-65 tahun dan mengunjungi klinik kecantikan minimal 1

Teknik analisa menggunakan statistik Structural Equation Modeling (SEM), yaitu untuk mengetahui hubungan kausalitas, validitas, dan reliabilitas sekaligus dari variabel penelitian ini. Menurut Edi (2018) Analisis SEM multi sampel adalah analisis untuk menguji perbedaan dengan membandingkan nilai-nilai parameter SEM antara sampel satu dengan sampel lainnya akibat 
Hompage: http://jurnal.umsu.ac.id/index.php/mbisnis

adanya variabel moderasi. Selanjutnya digambarkan frame work model SEM dengan 7 variabel laten.

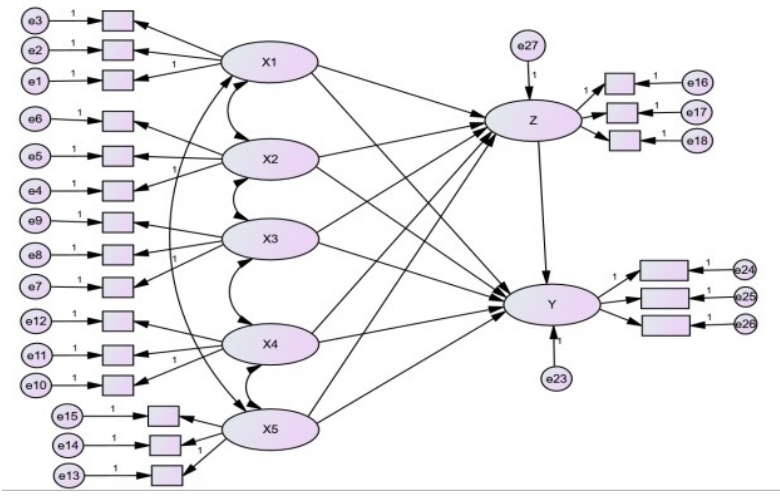

Gambar 2. Framework model SEM

Varibel laten dijelaskan oleh paling tidak tiga variabel manifes. Variabel laten dapat diukur dari pertanyaan variabel manifes. Pada model SEM, variabel laten dapat berfungsi sebagai variabel eksogen atau variabel endogen. Pada penelitian ini varibel Kepuasan Pelanggan $(\mathrm{Z})$ merupakan variabel endogen dari variabel $\mathrm{X} 1, \mathrm{X} 2, \mathrm{X} 3, \mathrm{X} 4, \mathrm{X} 5$ dan merupakan variabel eksogen dari variabel Loyalitas Pelanggan (Y)

Tabel 3.1 Definisi Operasinal

\begin{tabular}{|c|c|c|c|}
\hline Variabel & Definisi Operasional & Indikator & $\begin{array}{l}\text { Skala } \\
\text { pengukuran }\end{array}$ \\
\hline $\begin{array}{l}\text { Kualitas } \\
\text { (X1) }\end{array}$ & $\begin{array}{l}\text { Kualitasproduk merupakan } \\
\text { nilai, mutu yangmemberikan } \\
\text { tingkat kepuasan }\end{array}$ & $\begin{array}{l}\text { 1.Bebas dari efek samping } \\
\text { 2.Daya tahan produk stabil } \\
\text { 3.Mempunyai dampak } \\
\text { langsung dari kinerja produk }\end{array}$ & $\begin{array}{l}\text { Likert, } \\
\text { dimana nilai } \\
1=\text { sangat } \\
\text { tidak puas } \\
\text { dan nilai } \\
5=\text { sangat } \\
\text { puas }\end{array}$ \\
\hline $\begin{array}{l}\text { Kualitas } \\
\text { Pelayanan (X2) }\end{array}$ & $\begin{array}{l}\text { Kualitas pelayanan adalah } \\
\text { pelayanan yang diberikan } \\
\text { oleh klinik kecantikan } \\
\text { terhadap pelanggan dimana } \\
\text { pelanggan mendapatkan } \\
\text { sesuai dengan harapan } \\
\text { mereka. (Dimodifikasi dari } \\
\text { Eugenia dan Suryono, 2016) }\end{array}$ & $\begin{array}{l}\text { 1. Pelayanan yang diberikan } \\
\text { memuaskan } \\
\text { 2. Staf dan Beautician } \\
\text { memperhatikan kebutuhan } \\
\text { pelanggan dengan sungguh- } \\
\text { sungguh. } \\
\text { 3.Penanganan keluhan oleh } \\
\text { Beautician dan dokter } \\
\text { memuaskan }\end{array}$ & $\begin{array}{l}\text { Likert, } \\
\text { dimana nilai } \\
\text { 1= sangat } \\
\text { tidak puas } \\
\text { dan nilai } \\
5=\text { sangat } \\
\text { puas }\end{array}$ \\
\hline $\begin{array}{l}\text { Legalitas } \\
\text { (X3) }\end{array}$ & $\begin{array}{l}\text { Legalitas } \\
\text { adalahkepercayaan } \\
\text { pelanggan terhadap produk } \\
\text { kosmetik ijin resmi dan } \\
\text { sertifikasi yang sudah } \\
\text { terdaftar. (Dimodifikasi dari } \\
\text { Ratnawulan et.al,2017) }\end{array}$ & $\begin{array}{l}\text { 1.Terdapatnya label resmi pada } \\
\text { kemasan } \\
\text { 2.Produk terdaftar di BPOM } \\
\text { 3.Ada sertifikat MUI }\end{array}$ & $\begin{array}{l}\text { Likert, } \\
\text { dimana nilai } \\
1=\text { sangat } \\
\text { tidak puas } \\
\text { dan nilai } \\
5=\text { sangat } \\
\text { puas }\end{array}$ \\
\hline
\end{tabular}


Hompage: http://jurnal.umsu.ac.id/index.php/mbisnis

\begin{tabular}{|c|c|c|c|}
\hline Variabel & Definisi Operasional & Indikator & $\begin{array}{l}\text { Skala } \\
\text { pengukuran }\end{array}$ \\
\hline Kenyamanan (X4) & $\begin{array}{l}\text { Kenyamanan klinik adalah } \\
\text { suasana klinik dimana } \\
\text { pelanggan merasa nyaman } \\
\text { selama dilingkungan klinik } \\
\text { kecantikan. (Dimodifikasi } \\
\text { dari Nofiawaty dan Yuliandi } \\
.2014 \text { ) }\end{array}$ & $\begin{array}{l}\text { 1. Sikap karyawan, } \\
\text { persahabatan karyawan, } \\
\text { 2. dekorasi ruangan klinik } \\
\text { membuat rasa nyaman. } \\
\text { 3. Desain dan pengelolaan } \\
\text { Ruang tunggu terasa nyaman }\end{array}$ & $\begin{array}{l}\text { Likert, } \\
\text { dimana nilai } \\
1=\text { sangat } \\
\text { tidak puas } \\
\text { dan nilai } \\
5=\text { sangat } \\
\text { puas }\end{array}$ \\
\hline $\begin{array}{l}\text { Profesionalisme } \\
\text { (X5) }\end{array}$ & $\begin{array}{l}\text { Profesionalisme adalah sikap } \\
\text { dokter dalam menjalankan } \\
\text { jasa estetika, dokter dituntut } \\
\text { untuk mempunyai } \\
\text { kompetensi, sertifikasi } \\
\text { dibidang kecantikan kulit. } \\
\text { ( Dimodifikasi dari Abrori } \\
\text { et,al 2013). }\end{array}$ & $\begin{array}{l}\text { 1.Ahli medis Mempunyai } \\
\text { kompetensi di bidang } \\
\text { kecantikan perawatan kulit } \\
\text { 2.Ahli medis Mempunyai } \\
\text { sertifikasi pendidikan dibidang } \\
\text { kecantikan kulit } \\
\text { 3.Ahli medis menerima dan } \\
\text { menangani keluhan dengan } \\
\text { baik }\end{array}$ & $\begin{array}{l}\text { Likert, } \\
\text { dimana nilai } \\
1=\text { sangat } \\
\text { tidak puas } \\
\text { dan nilai } \\
5=\text { sangat } \\
\text { puas }\end{array}$ \\
\hline $\begin{array}{l}\text { Kualitas Pelayanan } \\
\text { (X2) }\end{array}$ & $\begin{array}{l}\text { Kualitas pelayanan adalah } \\
\text { pelayanan yang diberikan } \\
\text { oleh klinik kecantikan } \\
\text { terhadap pelanggan dimana } \\
\text { pelanggan mendapatkan } \\
\text { sesuai dengan harapan } \\
\text { mereka. (Dimodifikasi dari } \\
\text { Eugenia dan Suryono, 2016) }\end{array}$ & $\begin{array}{l}\text { 1. Pelayanan yang diberikan } \\
\text { memuaskan } \\
\text { 2. Staf dan Beautician } \\
\text { memperhatikan kebutuhan } \\
\text { pelanggan dengan sungguh- } \\
\text { sungguh. } \\
\text { 3.Penanganan keluhan oleh } \\
\text { Beautician dan dokter } \\
\text { memuaskan }\end{array}$ & $\begin{array}{l}\text { Likert, } \\
\text { dimana nilai } \\
1=\text { sangat } \\
\text { tidak puas } \\
\text { dan nilai } \\
5=\text { sangat } \\
\text { puas }\end{array}$ \\
\hline $\begin{array}{ll}\text { Legalitas } & \text { Produk } \\
\text { (X3) } & \end{array}$ & $\begin{array}{l}\text { Legalitas produk adalah } \\
\text { kepercayaan pelanggan } \\
\text { terhadap produk kosmetik } \\
\text { ijin resmi dan sertifikasi yang } \\
\text { sudah terdaftar. } \\
\text { (Dimodifikasi dari } \\
\text { Ratnawulan et.al ,2017) }\end{array}$ & $\begin{array}{l}\text { 1.Terdapatnya label resmi pada } \\
\text { kemasan } \\
\text { 2.Produk terdaftar di BPOM } \\
\text { 3.Ada sertifikat MUI }\end{array}$ & $\begin{array}{l}\text { Likert, } \\
\text { dimana nilai } \\
1=\text { sangat } \\
\text { tidak puas } \\
\text { dan nilai } \\
5=\text { sangat } \\
\text { puas }\end{array}$ \\
\hline Kenyamanan (X4) & $\begin{array}{l}\text { Kenyamanan klinik adalah } \\
\text { suasana klinik dimana } \\
\text { pelanggan merasa nyaman } \\
\text { selama dilingkungan klinik } \\
\text { kecantikan. (Dimodifikasi } \\
\text { dari Nofiawaty dan Yuliandi } \\
.2014 \text { ) }\end{array}$ & $\begin{array}{l}\text { 1. Sikap karyawan, } \\
\text { persahabatan karyawan, } \\
\text { 2. dekorasi ruangan klinik, dan } \\
\text { daya tarik atmosfer klinik } \\
\text { membuat rasa nyaman. } \\
\text { 3. Desain dan pengelolaan } \\
\text { Ruang tunggu terasa nyaman }\end{array}$ & $\begin{array}{l}\text { Likert, } \\
\text { dimana nilai } \\
1=\text { sangat } \\
\text { tidak puas } \\
\text { dan nilai } \\
5=\text { sangat } \\
\text { puas }\end{array}$ \\
\hline
\end{tabular}

\section{HASIL DAN PEMBAHASAN}

Modifikasi model dengan mengcovarian nilai error pada indikator dimaksudkan untuk mendapatkan model yang fit yang memenuhi kreteria yang ditentukan, dimana persyaratan Goodness of fit 4-5 terpenuhi (Hair at all,2010). Modifikasi pertama adalah membuat covarian antar indikator dari Modification indices nilai yang lebih besar. Dari output AMOS 24 pada Modification Indices modifiaksi pertama dipilih covarian antara e20-e21;e13-e22;e11-e17;e9e11;e6-e13;e4-e16. Kemudian pada modifikasi model ke dua adalah mengcovarian e6-21;e4e13;e5-e20;e15-e17 dan Z3 $\rightarrow$ 4-3 sehingga didapatkan model Fit. 


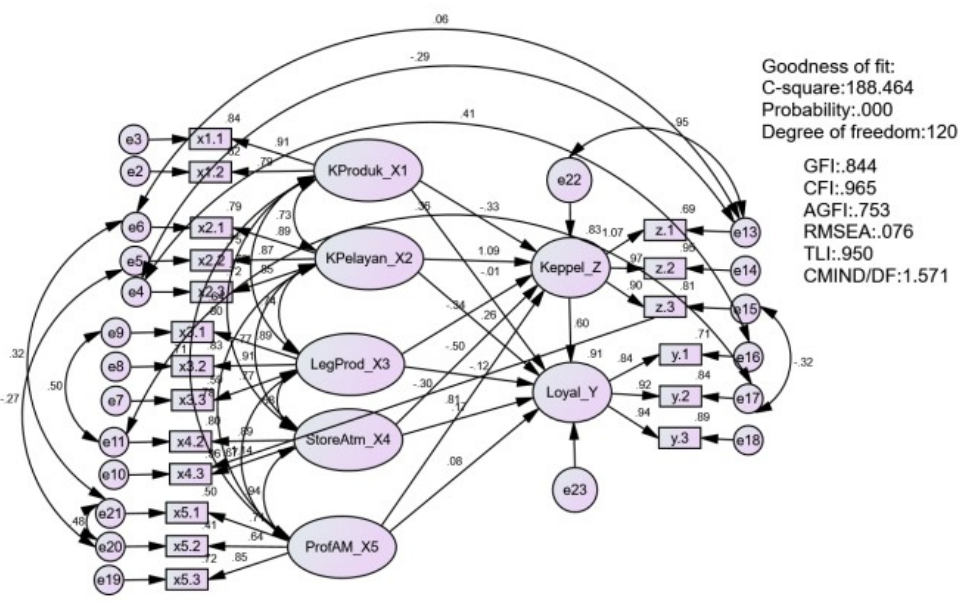

Gambar 3. Full Model Fit Sructure Equation Modeling

Tabel 1. Goodness of indeks - Fit

\begin{tabular}{llll}
\hline $\begin{array}{l}\text { Goodness of } \\
\text { fit indeks }\end{array}$ & Cut-of-value & Hasil Analisa & Kriteria \\
\hline $\begin{array}{l}\mathrm{X}^{2}(\text { Chi- } \\
\text { Square })\end{array}$ & 146.57 , prob .000 & 188.464 & Partial \\
& & & \\
Significance & $\geq 0.05$ & & \\
probability & & 0.000 & Not Good \\
RMSEA & $\leq 0.08$ & 0.076 & Good Fit \\
GFI & $\geq 0.90$ & 0.844 & Partial \\
AGFI & $\geq 0.90$ & 0.648 & Not Good \\
CMIN/DF & $\leq 2.00, \leq 5.00$ & 1.57 & Good Fit \\
TLI & $\geq 0.90$ & 0.950 & Good Fit \\
CFI & $\geq 0.90$ & 0.965 & Good Fit \\
\hline
\end{tabular}

Hasil modifikasi model terlihat pada gambar 3 dimana nilai CFI, RMSEA, TLI, CMIND/DF memenuhi kreteria yang ditentukan.

Tabel 2. Regression Weights: Scalar Estimate, Maximum Likelihood Estimates

\begin{tabular}{lll|lllll}
\hline & & & Estimate & S.E. & C.R. & P & Label \\
\hline Keppel_Z & $<---$ & KProduk_X1 & -.338 & .158 & -2.146 & .032 & par_13 \\
Keppel_Z & $<---$ & KPelayan_X2 & 1.444 & .272 & 5.319 & $* * *$ & par_14 \\
Keppel_Z & $<---$ & LegProd_X3 & -.362 & .183 & -1.981 & .048 & par_15 \\
Keppel_Z & $<---$ & StoreAtm_X4 & -.471 & .506 & -.931 & .352 & par_16 \\
Keppel_Z & $<---$ & ProfAM_X5 & 1.189 & .909 & 1.308 & .191 & par_22 \\
Loyal_Y & $<---$ & ProfAM_X5 & .098 & .295 & .332 & .740 & par_17 \\
Loyal_Y & $<---$ & KProduk_X1 & -.011 & .086 & -.125 & .900 & par_18 \\
Loyal_Y & $<---$ & KPelayan_X2 & .285 & .191 & 1.495 & .135 & par_19 \\
Loyal_Y & $<---$ & LegProd_X3 & -.110 & .081 & -1.346 & .178 & par_20 \\
Loyal_Y & $<---$ & StoreAtm_X4 & .131 & .154 & .854 & .393 & par_21 \\
Loyal_Y & $<---$ & Keppel_Z & .492 & .119 & 4.147 & $* * *$ & par_23 \\
\hline
\end{tabular}

Dari Tabel 2, Regression Weights, Maximum Likehood Estimate, terlihat pengaruh dari variabel dependen terhadap variabel independen pada nilai Critical Ratio. Pengaruh positif dan signifikan terdapat pada Kualitas Pelayanan (X2) tehadap Kepuasan Pelanggan (Z) dimana nilai CR 5,319 lebih besar 1,96 $\mathrm{p}^{* * *}$, Pengaruh positif dan signifikan juga pada Kepuasan Pelanggan (Z) terhadap Loyalitas (Y) dimana nilai CR 4,147 lebih besar dari 1,96 p *** 
Tabel 3. Standardized Regression Weigh

\begin{tabular}{lll|r}
\hline & & & Estimate \\
\hline Keppel_Z & $<---$ & KProduk_X1 & -.329 \\
Keppel_Z & $<---$ & KPelayan_X2 & 1.085 \\
Keppel_Z & $<---$ & LegProd_X3 & -.335 \\
Keppel_Z & $<---$ & StoreAtm_X4 & -.502 \\
Keppel_Z & $<---$ & ProfAM_X5 & .809 \\
Loyal_Y & $<---$ & ProfAM_X5 & .081 \\
Loyal_Y & $<---$ & KProduk_X1 & -.013 \\
Loyal_Y & $<---$ & KPelayan_X2 & .261 \\
Loyal_Y & $<---$ & LegProd_X3 & -.123 \\
Loyal_Y & $<---$ & StoreAtm_X4 & .171 \\
Loyal_Y & $<---$ & Keppel_Z & .600 \\
\hline
\end{tabular}

\section{Pengaruh Langsung, Tidak Langsung dan Pengaruh Total}

Analisis ini untuk melihat seberapa kuat pengaruh suatu variabel dengan variabel lainnya baik secara langsung, maupun secara tidak langsung. Menurut Haryono (2016) interpretasi dari hasil analisa statistik Amos dapat menjelaskan pengaruh langsung, tidak langsung dan pengaruh total. Dari model struktur juga dapat diketahui variabel-variabel yang mempunyai pengaruh cukup baik dengan adanya variabel mediasi (intervening).

Tabel 4. Pengaruh Langsung, Pengaruh Tidak Langsung. Pengaruh Total

\begin{tabular}{lllllll}
\hline & $\begin{array}{l}\text { Pengaruh } \\
\text { Langsung } \\
\text { (PL) }\end{array}$ & \multicolumn{2}{l}{$\begin{array}{l}\text { Pengaruh Tidak } \\
\text { Langsung (TL) }\end{array}$} & \multicolumn{2}{l}{ Pengaruh Total } \\
& KepPel & Loyalitas & KepPel & Loyalitas & KepPel & Loyalitas \\
ProfAM & 0,809 & 0,081 & 0 & 0,485 & 0,809 & 0,566 \\
StoreAtm & $-0,502$ & 0,171 & 0 & $-0,302$ & $-0,502$ & $-0,131$ \\
LegProd & $-0,335$ & $-0,123$ & 0 & $-0,201$ & $-0,335$ & $-0,324$ \\
Kpelayan & 1,085 & 0,261 & 0 & 0,651 & 1,085 & 0,912 \\
Kproduk & $-0,329$ & $-0,013$ & 0 & $-0,198$ & $-0,329$ & -021 \\
Keppel_Z & 0 & 0,06 & 0 & 0 & 0 & 0,6 \\
Loyal_Y & 0 & 0 & 0 & 0 & 0 & 0 \\
\hline
\end{tabular}

Berdasarkan hasil perhitungan dari statistik Amos pada Tabel Diatas, Profesional ahli medis dan kualitas pelayanan terhadap loyalitas pelanggan lebih besar daripada pengaruh langsung Profesional ahli medis dan kualitas pelayanan terhadap terhadap loyalitas pelanggan. Pengaruh langsung Profesional ahli medis terhadap loyalitas pelanggan sama dengan 0,081 dan pengaruh langsung antara kualitas pelayanan terhadap loyalitas 0,261 . Sedangkan pengaruh tidak langsung profesional ahli medis terhadap loyalitas pelanggan sama dengan 0,485 dan pengaruh tidak langsung antara kualitas pelayanan terhadap loyalitas 0,651. Terlihat bahwa adanya mediasi (intervening) dari variabel kepuasan yang menyebabkan pengaruh tidak langsung antara profesional ahli medis dan kualitas pelayanan terhadap loyalitas pelanggan mempunyai nilai lebih besar daripada pengaruh langsung. Terlihat bahwa adanya mediasi (intervening) dari variabel kepuasan yang menyebabkan pengaruh tidak langsung antara profesional ahli medis dan kualitas pelayanan terhadap loyalitas pelanggan mempunyai nilai lebih besar daripada pengaruh langsung. Menurut Haryono (2016) interpretasi tersebut dapat dilihat pada gambar berikut ini, dimana PL adalah pengaruh langsung dan TL adalah pengaruh tidak langsung. 


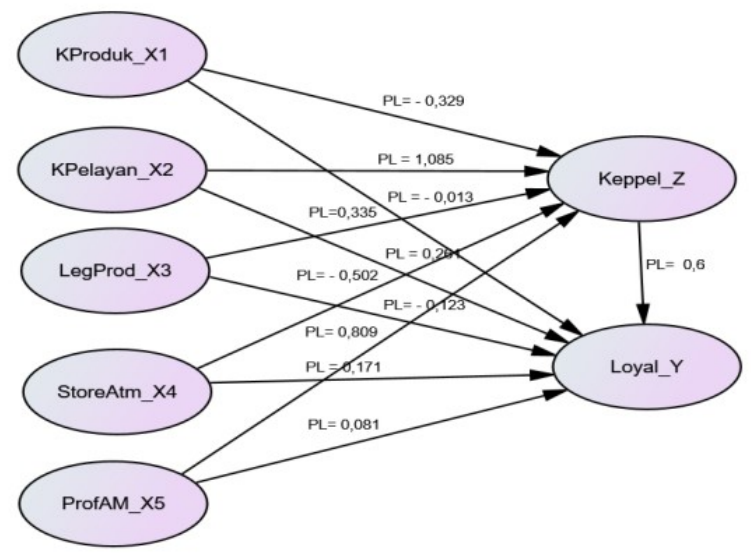

Gambar 4. Model Pengaruh Langsung

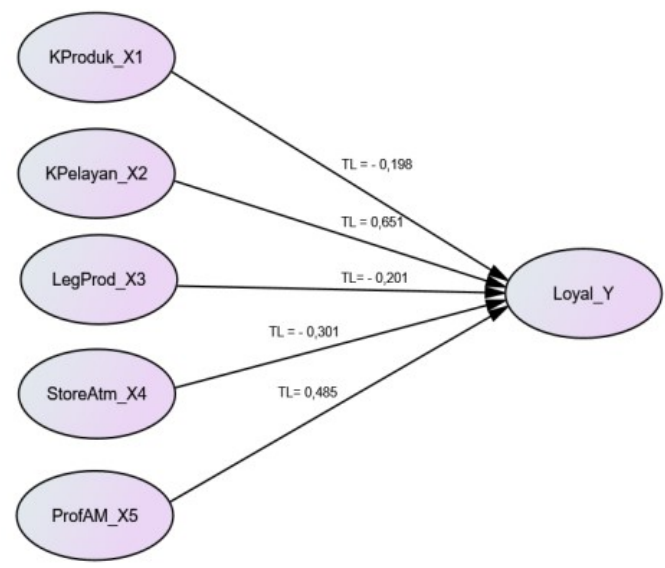

Gambar 5. Pengaruh TidakLangsung

\section{Pembahasan}

Dari analisa diperoleh Pengaruh Kualitas Produk terhadap Kepuasan Pelanggan berpengaruh negatif. Pengaruh negatif tersebut dapat dilihat pada hasil analisa Maximum Likelihood Estimate, nilai C.R. yaitu negatif. Menurut Hendry (2016) apabila nilai konstanta negatif maka dianggap tidak berpengaruh secara signifikan. Dari hasil analisa C.R. H1 tidak dapat diterima. Penelitian Eugenia dan Suryono (2016) kualitas produk berpengaruh positif dan signifikan terhadap kepuasan pelanggan tidak terbukti.

Pengaruh negatif pelanggan ini terlihat pada jawaban kuesioner pelanggan yang tidak setuju ataupun sangat tidak setuju pada jawaban pertanyaan kualitas produk seperti, Produk yang ditawarkan bebas dari efek samping, Daya tahan produk stabil tidak berubah-ubah, Produk yang saya konsumsi mempunyai dampak langsung terhadap keluhan saya. Implikasi yang ditimbul dari penelitian ini adalah klinik kecantikan hendaknya tetap melanjutkan komitmen meningkatkan kualitas produk untuk menjadikan pelanggan merasa puas sehingga tetap loyal kepada klinik kecantikan yang dikunjungi.

Kkualitas pelayanan berpengaruh positif dan signifikan terhadap kepuasan pelanggan. Pengaruh Positif tersebut adalah signifikan, hal ini dapat dilihat pada nilai C.R 5.319 $\geq 1,96$ dan nilai $\mathrm{p} \leq 0,05$ tanda $* * *$. Sejalan dengan penelitian Gissela Putri Yohana dan $\mathrm{Hj}$. Anik Lestari 
Andjarwati yang menyatakan kualitas pelayanan berpengaruh positif dan signifikan terhadap kepuasan terbukti. Penelitian Gissela dan Andjarwati, (2017) menyatakan bahwa kualitas pelayanan berpengaruh positif dan signifikan terhadap kepuasan pelanggan.

Implikasi dari penelitian ini adalah menunjukkan bahwa pelayanan yang dilakukan oleh staf office, beautician dan dokter ahli medis cukup baik dan memuaskan bagi pelanggan. Kualitas pelayanan berpengaruh positif dan signifikan terhadap kepuasan pelanggan menjadi terbukti.

Dari hasil analisa bahwa legalitas produk berpengaruh negatif terhadapkepuasan pelanggan. Pengaruh negatif tersebut dapat dilihat pada nilai konstanta C.R. negatif $(-1,981) p$ $0,032 \leq 0,05$. Menurut Hendry (2016) apabila nilai konstanta negatif maka dianggap tidak berpengaruh dan. Hipotesis H3 tidak diterima. Implikasi dari penelitian ini adalah beberapa responden merasa tidak puas terhadap beberapa faktor dari legalitas produk yang tidak tercantum pada kemasan produk. Meskipun pelanggan tetap mengkonsumsi produk yang ditawarkan, misalnya tidak adanya labelisasi halal pada produk tetapi pelanggan tetap membeli produk yang ditawarkan. Penelitian ini sejalan dengan penelitian Hayet tetntang pengaruh labelisasi halal terhadap pembelian produk kosmetik. Hayet (2019) apabila tidak tercantum labelisasi halal dari LPPOM MUI produk tersebut tetap dibeli oleh pelanggan. Dari pengamatan peneliti, alasan dari pelanggan untuk tetap mengkonsumsi produk tanpa labelisasi dikarenakan produk tersebut dapat mengatasi permasalahan kulit wajah yang sedang di konsultasikan meskipun adanya efek samping dalam kurun waktu tertentu.

Dari hasil analisa kenyamanan di klinik berpengaruh negatif terhadap kepuasan pelanggan. Sifat dari pengaruh negatif tersebut adanya nilai konstanta nigatif pada analisis C.R. $-0,931 \leq$ 1,96 dan $\mathrm{p} 0,352 \geq 0,05$. Rasa ketidaknyamanan pelanggan disebabkan karena lamanya waktu menunggu antrian untuk perawatan wajah atau konsultasi pada dokter, dan juga pengelolaan ruang tunggu yang tidak memenuhi harapan mereka misalnya pada waktu banyak antrian perawatan atau konsultasi ke dokter, pelanggan tidak mendapat tempat duduk sehingga menunggu sambil berdiri. Hipotesis H4 Tidak Diterima. Penelitian Lucky dan Sumarto (2010) menyatakan aktifitas toko atau suasana klinik memberikan rasa nyaman berpengaruh positif terhadap kepuasan tidak terbukti.

Pada Regression Weights, dapat diketahui bahwa dimensi maupun indikator dari Full Mode Fit tidak memenuhi kreteria (karena nilai C.R. $\leq 1,96$ atau nilai $\mathrm{P} \geq 0,05$ ). Dari output Amos 24 terlihat nilai critical ratio $1.308 \leq 1,96$ dan $p 0,191 \geq 0,05$. maka hipotesis ke lima tidak diterima, artinya profesional ahli medis tidak berpengaruh secara positif dan signifikan terhadap kepuasan pelanggan. Implikasi dari analisa ini adalah meskipun ahli medis mempunyai kompetensi, sertifikasi dibidang kecantikan kulit wajah masih ada pelanggan belum terpuaskan sehinggan masih terdapat kecenderungan untuk berpindah dan mencari tindakan perawatan wajah sesuai yang mereka harapkan.

Dari hasil analisa bahwa kualitas produk berpengaruh negatif terhadap loyalitas pelanggan. Pengaruh negatif tersebut dapat dilihat pada nilai konstanta C.R. negatif $(-0,125) \mathrm{p} 0,90 \geq 0,05$. Menurut Hendry (2016) apabila nilai konstanta negatif maka dianggap tidak berpengaruh dan Hipotesis H6 tidak diterima. Implikasi dari penelitian ini adalah klinik kecantikan dapat menyediakan produk yang memiliki stabilitas mutu lebih baik. Konsistensi produk seperti cream, toner dan serum tidak berubah baik kekentalan, aroma maupun warna sehingga dapat meningkatkan loyalitas pelanggan.

Berdasarkan dimensi maupun indikator dari Full Mode Fit tidak memenuhi kreteria (karena nilai C.R. $\leq 1,96$ atau nilai $\mathrm{P} \geq 0,05$ ). Dari output Amos 24 terlihat nilai critical ratio $1.308 \leq 1,96$ dan p $0,191 \geq 0,05$. maka hipotesis ke tujuh tidak diterima, artinya profesional ahli medis tidak berpengaruh secara positif dan signifikan terhadap kepuasan pelanggan. Implikasi dari analisa ini adalah meskipun ahli medis mempunyai kompetensi, sertifikasi dibidang 
kecantikan kulit wajah masih ada pelanggan belum terpuaskan sehinggan masih terdapat kecenderungan untuk berpindah dan mencari tindakan perawatan wajah sesuai yang mereka harapkan.

pengaruh legalitas produk terhadap loyalitas negatif. Nilai C.R $-1.346 \leq 1,96$ atau nilai P $0,178 \geq 0,05$. Tanda nigatif pada konstanta critical ratio memberikan informasi tidak ada pengaruh antara legalitas produk dengan loyalitas. H8 tidak diterima. Signifikansi dari output Amos 24 terlihat pada Tabel 4.22 nilai critical ratio $-2,146 \leq 1,96$ dan p $0,032 \leq 0,05$. maka hipotesis pertama ditolak, artinya kualitas produk berpengaruh negatif dan signifikan terhadap kepuasan pelanggan..

Berdasarkan output AMOS 24 pada Regression Weights: (Group number 1 - Default model) di atas dapat diketahui bahwa dimensi maupun indikator dari Full Mode Fit tidak memenuhi kreteria (karena nilai C.R. $\leq 1,96$ atau nilai $\mathrm{P} \geq 0,05$ ). Dari output Amos 24 Terlihat pada Tabel 4.22 nilai critical ratio $-0.854 \leq 1,96$ dan $p 0,393 \geq 0,05$. maka hipotesis ke sembilan ditolak, artinya kenyamanan klinik berpengaruh negatif terhadap loyalitas pelanggan.

Ketidaknyamanan yang dirasakan oleh pelanggan karena menunggu antrian terlalu lama atau tidak mendapat tempat duduk menjadi perhatian penting bagi klinik kecantikan untuk meningkatkan loyalitas pelanggan. Klinik kecantikan membuat jadwal perawatan atau konsultasi ke ahli medis bagi pelanggan, atau mempercepat keinginan pelanggan berdasarkan data pada kartu kunjungan pelanggan

Berdasarkan output AMOS 24 pada Regression Weights di atas dapat diketahui bahwa dimensi maupun indikator dari Full Mode Fit tidak memenuhi kreteria (karena nilai C.R. $\leq 1,96$ atau nilai $\mathrm{P} \geq 0,05$ ). Dari output Amos 24 terlihat nilai critical ratio $0.332 \leq 1,96$ dan $\mathrm{p} 0,740 \geq$ 0,05. maka hipotesis ke lima tidak diterima, artinya profesional ahli medis tidak berpengaruh secara positif dan signifikan terhadap loyalitas pelanggan. Implikasi dari penelitian ini adalah meskipun ahli medis mempunyai kompetensi, sertifikasi dibidang kecantikan kulit wajah tidak menjadikan retensi loyalitas bagi pelanggan, masih terdapat kecenderungan pelanggan untuk berpindah. Pertumbuhan klinik kecantikan perawatan kulit wajah di kota Palembang pada saat ini menjadikan bahan pertimbangan bagi klinik kecantikan untuk berfokus pada pelanggan yang rutin melakukan perawatan maupun mengkonsumsi produk perawatan. Meningkatkan kompetensi baik tindakan medis maupun sertifikasi pendidikan dibidang estetika perawatan kulit dan kecantikan wajah. Kepuasan pelanggan berpengaruh positif dan signifikan terhadap loyalitas pelanggan di klinik kecantikan kota Palembang. Ida dan Mandala, (2019) dampak kedepan dari pelanggan yang sudah terpuaskan akan menciptakan loyalitas pelanggan. Pelanggan yang loyal, akan merekomendasikan klinik kecantikan yang sudah dikunjunginya kepada orang lain. Gissela dan Andjarwati, (2017) kualitas pelayanan berpengaruh positif dan signifikan terhadap kepuasan, dan kepuasan berpengaruh positif dan signifikan terhadap loyalitas.

\section{SIMPULAN}

Kualitas produk merupakan hal yang penting bagi pelanggan. Tetapi dari respon kuesioner beberapa pelanggan klinik kecantikan di Palembang memberikan responen negatif. Ini merupakan informasi penting untuk klinik kecantikan agar supaya produk yang disediakan memenuhi beberapa persyaratan kualitas produk yang disediakan yaitu kestabilan produk, produk yang dikonsumsi oleh pelanggan tidak mempunyai efek samping, dan kinerja dari produk dapat segera mengatasi permasalahan kulit muka dari pelanggan.

Kualitas Pelayanan prima memiliki pengaruh yang positif dan signifikan terhadap kepuasan pelanggan. Klinik kecantikan di kota Palembang perlu untuk mempertahankan dan meningkatkan pelayanan terhadap pelanggan. Pelanggan yang merasa di perhatikan serta mendapat pelayanan terbaik, menjadikan harapan dan keinginan dari pelanggan terpenuhi. 
Legalitas produk berpengaruh negatif terhadap kepuasan pelanggan. Hal ini ada beberapa responden memberikan jawaban tidak setuju terhadap pertanyaan kuesioner tentang beberapa persyaratan legalitas, tidak tercantumnya persyaratan, seperti persyaratan label resmi dari BPOM dan juga label halal dari Majelis Ulama Indonesia. Kenyamanan klinik berpengaruh negatif terhadap kepuasan pelanggan. Walaupun kenyamanan berpengaruh negatif, tetapi pelanggan klinik kecantikan di palembang menyatakan loyal. Hal ini ada beberapa pelanggan yang sudah perawatan dalam kurun waktu lama dan relationship yang baik terhadap klinik, beautician dan ahli medis serta rutin mengkonsumsi produk dari klinik yang dikunjungi. Jill Griffin (2002:5) mengungkapkan apabila kepuasaan pelanggan tidak dapat diandalkan, pengukuran yang terkait dengan pembelian ulang adalah loyalitas pelanggan (customer loyalty).

Profesionalisme ahli medis berpengaruh positif dan signifikan terhadap kepuasan pelanggan. Perawatan oleh beautician dan tindakan perawatan yang dilakukan oleh dokter memberikan efek positif bagi kepuasan pelanggan. Efek kepuasan ini ternyata tidak disertai loyalitas. Pelanggan yang tidak loyal mencari klinik kecantikan lainnya yang dapat mengatasi permasalahan kulit muka yang sedang dialami. artinya profesional ahli medis tidak berpengaruh secara positif dan signifikan terhadap kepuasan pelanggan. Implikasi dari analisa ini adalah meskipun ahli medis mempunyai kompetensi, sertifikasi dibidang kecantikan kulit wajah masih ada pelanggan belum terpuaskan sehinggan masih terdapat kecenderungan untuk berpindah dan mencari tindakan perawatan wajah sesuai yang mereka harapkan. Untuk menciptakan loyalitas pelanggan klinik kecantikan di kota Palembang, maka hal yang penting juga dapat menyediakan produk yang memiliki stabilitas mutu lebih baik. Konsistensi produk seperti cream, toner dan serum tidak berubah baik kekentalan, aroma maupun warna sehingga dapat meningkatkan loyalitas pelanggan. Kepuasan Pelanggan berpengaruh positif dan signifikan terhadap loyalitas pelanggan. Nilai Kritikal Rasio yang cukup baik dipengaruhi oleh beberapa faktor diantaranya memberikan pelayan yang cukup baik kepada pelanggan sehingga menjadikan perasaan kepuasan pada pelanggan, faktor lainnya walaupun mempunyai pengaruh yang tidak signifikan adalah penanganan keluhan terhadap pelanggan yang baik dari staf office, ahli beautician maupun oleh dokter. Untuk mempertahankan loyalitas pelanggan berkelanjutan, perlu kiranya mempertahankan faktor-faktor tersebut diatas bahkan berusaha untuk meningkatkannya.

\section{REFERENSI}

Adi Ruslan, S. K. dan F. R. (2015) Pengaruh Kualitas Layanan Terhadap Kepuasan Usaha, Membentuk Loyalitas Pelanggan (Studi Kasus Pada Pekanbaru), Pondok Durian Pangeran. Jurnal Dinamika Pertanian, Volume XXX.

Afif Nur ZAIM, I. M. (2014). Pengaruh Pembiayaan Murabahah Terhadap Laba Melalui Variabel Intervening Pembiayaan Bermasalah Bank Umum Syariah Di Indonesia Periode 2009-2013. Jestt, 1(8), 565-580.

Arshad, R., Akbar, I., Muqtadir, A., Shafique, U., Zia, H., Naseer, W., \& Amin, A. (2007). Impact of Brand Switching, Brand Credibility, Customer Satisfaction and Service Quality on Brand Loyalty. Journal Of Business and Management, 12-20. http://iosrjournals.org/iosr-jbm/papers/ndbmr-volume-1/B.pdf

Aryamti Septian Amelia, A. S. (2019). Analisis Kualitas Produk, Kualitas Pelayanan Dan Citra Merek Pada Kepuasan Pelanggan Klinik Kecantikan Dan Pengaruhnya Terhadap Loyalitas. E-Proceeding Of Management, 6(1), 131-138.

Aryani, D., \& Rosinta, F. (2010). Pengaruh Kualitas Layanan terhadap Kepuasan Pelanggan dalam Membentuk Loyalitas Pelanggan. Jurnal Ilmu Administrasi Dan Organisasi, 17(2), 114-126. 
Asti, E., \& Ayuningtyas, E. (2020). Pengaruh Kualitas Pelayanan, Kualitas Produk Dan Harga Terhadap Kepuasan Konsumen. EKOMABIS: Jurnal Ekonomi Manajemen Bisnis, 1(01), 114. https://doi.org/10.37366/ekomabis.v1i01.2

Bharada, R. J. (2018). a Study of Brand Loyalty for Cosmetic Products Among Youth in Rajkot City. Abhinav National Monthly Refereed Journal of Research in Commerce \& Management, 7(3), 8-21. https://doi.org/10.13140/RG.2.2.18173.82402

Bin Junaid, A. (2014). Indian Cosmeceutical Market: A Study of Consumer Preferences and Consumption Patterns. Journal of Clinical \& Experimental Dermatology Research, 05(02). https://doi.org/10.4172/2155-9554.1000212

Burhan, B. (2011). Metodologi Penelitian Kuantitatif(Kedua). Kencana Prenadamedia Group.

Chiou, J. S., \& Droge, C. (2006). Service quality, trust, specific asset investment, and expertise: Direct and indirect effects in a satisfaction-loyalty framework. Journal of the Academy of Marketing Science, 34(4), 613-627. https://doi.org/10.1177/0092070306286934

Cindra, S., Yahya, K., \& Faktor, A. A. (2012). Analisis Statistik Kepuasaan Pelayanan Klinik Kecantikan London Beauty Centre Cabang Manyar Kertoajo Surabaya. 1(1).

Dehghan, A., \& Shahin, A. (2011). Customer Loyalty Assessment-A Case Study in MADDIRAN, the Distributor of LG Electronics in Iran. Business Management and Strategy, 2(1), 2. https://doi.org/10.5296/bms.v2i1.628

Dennisa, E. A., \& Santoso, S. B. (2016). Analisis Pengaruh Kualitas Produk, Kualitas Layanan, dan Citra Merek terhadap Loyalitas Pelanggan melalui Kepuasan Pelanggan sebagai Variabel Intervening (Studi pada Klinik Kecantikan Cosmedic Semarang). JOURNAL OF MANAGEMENT, Issn 2337-3792, 5(3), 1-13.

Dharmmesta Swastha Basu, Florensia Kurnia Puung, A. F. (2014). Analisis Pengaruh Kualitas Pelayanan Pada Kepuasan Dan Loyalitas Pelanggan Di Salon Dan Spa. Jurnal Manajemen Dan Pelayanan Farmasi Universitas Gadjah Mada, Yogyakarta, 4(2), 105-110. https://doi.org/10.22146/jmpf.274.

Djumarno, Anjani, S., \& Djamaluddin, S. (2018). Effect of Product Quality and Price on Customer Loyalty through Customer Satisfaction. International Journal of Business and $\begin{array}{llll}\text { Management Invention } & \text { (IJBMI), } & \text { 7(8), }\end{array}$ http://www.ijbmi.org/papers/Vol(7)8/Version-1/C0708011320.pdf

Donni, P. J. (2017). Perilaku Konsumen Dalam Persaingan Kontemporer. In I. P. I. Anggota (Ed.), alfabeta (Cetakan Ke). AlfaBeta Bandung.

Donni, P. J. (2017). Perilaku Konsumen Dalam Persaingan Kontemporer (I. P. I. Anggota (ed.); Cetakan ke). AlfaBeta Bandung.

Ergin, E. A., Ozdemir, H., \& Parilti, N. (2011). Brand Loyalty In The Cosmetics Industry: A Field Study On Turkish Womens Brand Loyalty Among Cosmetics Products. In Journal of Business \& Economics Research (JBER) (Vol. 3, Issue 5). https://doi.org/10.19030/jber.v3i5.2771

Eziswita, S. T. dan. (2018). Analisis Experiential Marketing Dan Pengaruhnya Terhadap Kepuasan Pasien (Studi Pada Klinik Sehat Gajah Mada Di Kota Padang) Padang). Menara Ekonomi, Volume IV. https://doi.org/ISSN : 2407-8565; E-ISSN: 2579-5295

Ferdinand, A. (2002). Structural Equation Modeling Dalam Penelitian. Balai Pustakan Undip.

Ferdinand, A. (2014). Metode Penelitian Manajemen (Kelima). Badan Penerbit Universitas Diponegoro.

Hadrawi, M. (2017). 'Tidak Menang Tampang Doang': Kombinasi Outer dan Inner Beauty di Kalangan Mahasiswi. Etnosia: Jurnal Etnografi Indonesia, 3, 22-47. https://doi.org/http://dx.doi.org/10.31947/etnosia.v3i1.3608 
Hamza, K. S. (n.d.). The Influence of Brand Loyalty on Cosmetics Buying Behavior of UAE Female Consumers. International Journal of Marketing Studies, Vol 3 No 2. https://doi.org/doi:10.5539/ijms.v3n2p123

Hardaningsih. (2018). Laporan Tahunan Balai Besar POM di Palembang. In Bandan POM.

Hayet. (2019). Pengaruh Labelisasi Halal Terhadap Keputusan Pembelian Produk Kosmetik (Studi Kasus Di Kota Pontianak, Kalimantan Barat, Indonesia). Jurnal Ekonomi Islam, Volume 10. https://doi.org/DOI: 10.32678/ijei.v10i1.119

Icshan, R. (2018). Konsep Diri Pria Metroseksual Di Kota Pekanbaru. Jom Fisip, 5(Edisi II), 3.

Isnurhadi1, Wahab2, Z., Muthia3, F., \& Bashir, A. (2019). Identifying The Factors Determining Of Muslims' Intention To Adopt Islamic Banking In The Local Region: Religiosity As Moderating Variable. Humanities \& Social Sciences Reviews, Vol 8,. https://doi.org/https://doi.org/10.18510/hssr.2020.8255

Išoraite, M. (2016). Customer Loyalty Theoretical Aspects. Vilniaus Kolegija/University Applied Sciences, Lithuania, 5(Issue 2 (9)).

Jannah, A. N., Ahri, R. A., \& Yusriani, Y. (2019). Pengaruh Pengalaman Konsumen Terhadap Loyalitas Pemanfaatan Di Md Clinic Makassar Tahun 2018. Jurnal Ilmiah Kesehatan Diagnosis, 14(3), 275-282. https://doi.org/10.35892/jikd.v14i3.249

Juliani, F. A. (2015). Pengaruh Switching Barrier Terhadap Loyalitas Pelanggan. Ilmu Manajemen, 2(April), 131-134. https://doi.org/ISSN : 2355-6099

Keller Lane Kevin, P. K. (2009). Manajemen Pemasaran (A. M. Hardani Wibi (ed.); Tigabelas). Erlangga.

Mandala2, I. A. K. S. S. K. (2018). Pengaruh Persepsi Harga, Promosi Penjualan, Dan Citra Merek Terhadap Kepuasan Untuk Meningkatkan Loyalitas Pelanggan. E-Jurnal $\begin{array}{llll}\text { Manajemen Universitas } & \text { Udayana, } & 8(1),\end{array}$ https://doi.org/10.24843/ejmunud.2019.v08.i01.p04

Mao, J. (2010). Customer Brand Loyalty. International Journal of Business and Management, 5(7), 213-217. https://doi.org/10.5539/ijbm.v5n7p213

Mardalis Ahmad. (n.d.). Meraih Loyalitas Pelanggan. Manajemen Dan Bisnis, Vol. 9, No, 111119. https://doi.org/Akreditasi No. 23a / DIKTI / KEP / 2004 ISSN 1410 - 4571 BENEFIT

Martam K Nurmin, Fatma Riska Fitrianingsih Dai, R. K. (n.d.). Perlindungan Hukum Bagi Konsumen Terhadap Peredaran Kosmetik Ilegal. Seminar Nasional Teknologi, Sains Dan Humaniora. https://doi.org/ISBN: 978-623-91695-3-4

May, C. L. (2017). Jaminan Produk Halal di Indonesia. Jurnal Legislasi Indonesia, 14(1), 99108.

Mikhriani, M. (2012). Analisis Segmentasi Pasar Perawatan Kulit Wajah Natasha Skin Care Yogyakarta. Jurnal Dakwah, 13(1), 105-136. http://ejournal.uinsuka.ac.id/dakwah/jurnaldakwah/article/view/321/299

Monalisa, \& Mahendra, I. (2017). Sistem Informasi Klinik Berbasis Web Pada Klinik Umum Dan. CKI On Spot, 10(2598-2990)

Murwani Juli, Isharijadi, A. L. S. (2013). Pengaruh Kepuasan Pelanggan Terhadap Niat Berkunjung Ulang (Study Pada Klinik Kecantikan V-Chen Medicart Clinic) Aries. Forum Ilmiah Pendidikan Akuntansi Progam Studi Pendidikan Akuntansi-Fkip Universitas Pgri Madiun, 1-11.

Nadaa, Z. (207 C.E.). Pengaruh Desain Interior Pada Faktor. Jurnal Desain \& Seni, FDSK $U M B$

239-257.

http://publikasi.mercubuana.ac.id/index.php/narada/article/view/3223/1776

Ndubisi, N. O. (2007). Relationship marketing and customer loyalty. Marketing Intelligence and Planning, 25(1), 98-106. https://doi.org/10.1108/02634500710722425 
Nguyen, N., Leclerc, A., \& LeBlanc, G. (2013). The Mediating Role of Customer Trust on Customer Loyalty. Journal of Service Science and Management, 06(01), 96-109. https://doi.org/10.4236/jssm.2013.61010

Olive L. Richard. (1997). Satisfaction A Behavioral Perspektif On The Consumer.

Putri Yohana, G. (2017). Pengaruh Kualitas Layanan Dan Harga Terhadap Kepuasan Dan Loyalitas Pelanggan (Studi Pada Pelanggan Medin Beauty). Jurnal Ilmu Manajemen (JIM), 5(3), 1-9.

Qonitat, N. N., Suyadi, I., \& Sunarti. (2018). Pengaruh Kepuasan Pelanggan, Switching Barrier dan Kepercayaan Merek Terhadap Customer Retention (Survei pada Mahasiswa S1 Universits Brawijaya Malang Pelanggan Produk Merek Wardah ). Jurnal Administrasi Bisnis (JAB), 55(2), 57-67.

Rossellini, N., \& Suhariadi, F. (2013). Hubungan antara Kepuasan Pelanggan dengan Word of Mouth pada Pelanggan Klinik Kecantikan London Beauty Centre. Jurnal Psikologi Industri Dan Organisasi, 2(3), 169-176. http://journal.unair.ac.id/download-fullpapersjpioca23a678162full.pdf

Saifuddin, A. (n.d.). Signifikan atau Sangat Signifikan. Buletin Psikologi, Volume 13, 38-44. https://doi.org/10.22146/bpsi.13410

Salim Khraim, H. (2011). The Influence of Brand Loyalty on Cosmetics Buying Behavior of UAE Female Consumers. International Journal of Marketing Studies, 3(2). https://doi.org/10.5539/ijms.v3n2p123

Sarwono, J. (2010). Pengertian Dasar Structural Equation Modeling ( Sem ). Jurnal Ilmiah Manajemen Bisnis, Vol. 10, N, 173-182.

Sezgin, M., \& Küçükköylü, S. (2014). Store's Atmosphere's Importance in Creating Store's Image in Sustainable Management of Store and a Research in Konya(Turkey) City. Journal of Advanced Management Science, 2(3), 186-191. https://doi.org/10.12720/joams.2.3.186191

Soraya Ratnawulan Mita*, Patihul Husni, I. K. S. (2017). Cara Menghindari Kosmetika Palsu dengan Organoleptik. Majalah Farmasetika, Vol. 2

Steffi, M. A., Widha, S. N., Oktavianty, O., \& . (2013). Analisis Pengaruh Pelayanan Prima Terhadap Kepuasan Nasabah Dan Loyalitas Nasabah Menggunakan Structural Equation Modeling. Jurnal Rekayasa Dan Manajemen Sistem Industri Vol. 3

Sugiyarti, G. (2017). Experiential Marketing Creative Antecedence for Success of Brand Loyalty (A Study on the Users of Perfume for Body in Indonesia). International Review of Management and Marketing, 7(1), 529-536.

Sugiyono. (2010). Penelitian Pendidikan. AlfaBeta Bandung.

Suharsimi Arikunto. (2009). Manajemen Penelitian. Rineka Cipta.

Susila, B., Sumarwan, U., \& Kirbrandoko. (2014). Analisis Kepuasan Konsumen Terhadap Brand SwitchinG Abstrak Analysis of Consumer Satisfaction and Brand Switching Behavior of Ready to Drink ( RTD ) Tea Abstract. Jur. Ilm. Kel. \& Kons., 7(3), 193-201.

Tekin, G., Yiltay, S., \& Ayaz, E. (2016). Internatonal Journal of Academic Value Studies The Effect of Brand Image on Consumer Behaviour: Case Study of Louiss Vuitton-Moet Hennessy. Internatonal Journal of Academic Value Studies, 2(2), 1-24. www.javstudies.com

Uncles, M. D., Dowling, G. R., \& Hammond, K. (2003). Customer loyalty and customer loyalty programs. Journal of Consumer Marketing, 20(4-5), 294-316. https://doi.org/10.1108/07363760310483676

Wahyono, I. W. W. (2015). Pengaruh Kualitas Pelayanan, Persepsi Harga Dan Nilai Pelanggan Terhadap Loyalitas Konsumen Melalui Kepuasan Pelanggan Sebagai Variabel Intervening. 
Jurusan Manajemen, Fakultas Ekonomi, Universitas Negeri Semarang, Semarang, Indonesia. https://doi.org/ISSN 2252-6552

Waluyo, . Minto. (2016). Mudah Cepat Tepat Penggunaan Tools Amos Dalam Aplikasi (SEM). In I. Basuki (Ed.), UPN Jatim (2016th ed.). UPN "Veteran" Jawa Timur.

Willy, A., \& Mutis, T. (2018). The Research of Customer Switching Behavior at Some Leasing Companies. International Review of Management and Marketing, 8(1), 115-118. https://doi.org/ISSN: 2146-4405

Wu, Y. L., \& Li, E. Y. (2018). Marketing mix, customer value, and customer loyalty in social commerce: A stimulus-organism-response perspective. Internet Research, 28(1), 74-104. https://doi.org/10.1108/IntR-08-2016-0250

Yayi Suryo Prabandar Suryo Yayi, Mora Claramita, C. B. P. (2015). Pembelajaran Profesionalisme Kedokteran dalam Persepsi Instruktur dan Mahasiswa. JurnalPendidikanKedokteranIndonesia, 4(1), 21-27. https://doi.org/10.22146/jpki.25263

Yu, Y. T., \& Dean, A. (2001). The contribution of emotional satisfaction to consumer loyalty. International Journal of Service Industry Management, 12(3), 234-250. https://doi.org/10.1108/09564230110393239

Yulia, A. P. (2014). Analisis Faktor-Faktor Yang Mempengaruhi Minat Perpindahan Merek Dengan Reference Group Sebagai Variabel Moderating (Studi kasus pada pengguna provider Indosat M3 di Kota Semarang). Jurnal Manajemen Pemasaran Indonesia, 2, 189210. 